\title{
A Literature Review on the Definition and Process of Project-Based Learning and Other Relative Studies
}

\author{
Xiaomei Du, Jie Han \\ Foreign Languages Department, Baoding University, Baoding, China \\ Email: duxiaomei2013@163.com
}

Received 14 April 2016; accepted 28 May 2016; published 31 May 2016

Copyright (C) 2016 by authors and Scientific Research Publishing Inc.

This work is licensed under the Creative Commons Attribution International License (CC BY). http://creativecommons.org/licenses/by/4.0/

c) (i) Open Access

\begin{abstract}
Project-Based Learning (PBL) is a student-centered model that organizes learning and studying around projects. It has gained some popularity in second language education and exercised positive influence on educational practices. This paper gives a selective review of the researches on Project-Based Learning from different aspects, including the definition of PBL, the process of PBL and other relative studies, in the hope that this may, to some extent, render help to teachers who employ PBL in varying degrees.
\end{abstract}

\section{Keywords}

Project-Based Learning, Review, Studies

\section{Introduction}

The National Standards of Teaching Quality for Undergraduate English Majors lays great emphasis on cultivating the students' overall competence to use English language proficiently, and think critically and innovatively. Under the guidance of the national standards, English teaching is entering into a new era. Meanwhile, English teachers must make efforts to figure out new and effective ways to improve students' language proficiency in order to meet the new standards. In fact, the ultimate objective of English learning is to use English in real life or authentic contexts. Thus, it is suggested that Project-Based Learning (PBL) should be taken into consideration. Since it can render help in achieving the objectives, especially enhancing the use of English in practical communication. Meanwhile, a survey of western studies is necessary and meaningful since it may shed light on the relevant studies or practices in China. This paper gives a review of the researches of Project-Based Learning from different aspects, including the definition of Project-Based Learning, the process of Project-Based Learning and 
its relative studies.

\section{Definition of Project-Based Learning (PBL)}

The Project-based learning has been part of the educational practice approximately at the beginning of the 1980s and it was greatly influenced by the communicative approach. Nowadays, as an appropriate and effective method, it is widely used in the teaching of English as a second language.

The history of PBL can be traced back to the progressive tradition advocated by John Dewey. Dewey insisted on the idea of "learning by doing". He argued that the classroom should be a kind of society and the students should be encouraged to become the center in the learning process.

Legutke and Thomas (1991) define project work as a learner and task-centered mode of teaching and learning which results from a joint process of discussion between all participants.

Project is an extended task which usually integrates language skills through a number of activities (Hedge, 1993). It involves a number of features: the use of authentic English language materials, an emphasis on integrity and student-centered activities, the importance of students' participation and the use of different skills. It is also defined as "an instructional approach that contextualizes learning by presenting learners with problems to solve or products to develop" (Moss \& Van Duzer, 1998). Project work encourages creativity, critical thinking, collaboration, self-study, and other study skills.

Project-based learning is a very effective approach that allows the students to throw out opinions about the topics covering fields of interest, to ask questions, to estimate, to develop theories, to use different tools, to use the skills acquired in the context of a real and meaningful life and allows learner to solve problems and answer questions in a creative way in the classroom and outside (Katz \& Chard, 2000).

Thomas's adopts five criteria to define PBL: 1) "Projects are central, not peripheral to the curriculum"; 2) "projects are focused on questions or problems that 'drive' students to encounter (and struggle with) the central concepts and principals of the discipline"; 3) "projects involve students in a constructive investigation"; 4) "projects are student-driven to some significant degree"; and 5) "projects are realistic, not school-like". Collaboration, as a matter of fact, should also be included as a sixth criterion of PBL (Thomas \& Mergendoller, 2000).

Stoller (2006) defines PBI as: 1) having a process and product; 2) giving students (partial) ownership of the project; 3) extending over a period of time (several days, weeks, or months); 4) integrating skills; 5) developing students' understanding of a topic through the integration of language and content; 6) collaborating with other students and working on their own; 7) holding students responsible for their own learning through the gathering, processing, and reporting of information from target language resources; 8) assigning new roles and responsibilities to students and teacher; 9) providing a tangible final product; and 10) reflecting on both the process and the product. Thus, it is different from the traditional English teaching in that it lays great emphasis on the communicative and functional aspect of language learning and it also pays attention to the integrity of language and content learning.

It is obvious that the definition of PBL is changing from time to time. This diversity of defining features coupled with the lack of a universally accepted model or theory in Project-based learning has finally led to a variety of PBL researches and development activities, which rendered great complexity to this issue. Fortunately, there are still some overlaps in these design features.

\section{The Process of Project-Based Learning (PBL)}

Papandreou maintains that every project is the result of a series of activities conducted by the students and these activities are organized into a process. That is to say every project is composed of certain stages. Wrigley argues that most project work covers the following steps: topic selecting, planning, researching and products-making. Studies on the process of PBL varies from each other, however, they share certain core features or steps.

There are a variety of approaches to present the PBL in English teaching classrooms. Fried Booth (1986) argues that a project actually covers three stages: beginning in the classroom, moving out into the world, and returning back to the classroom. This model later develops into the eight stages of development.

Papandreou (1994) in "An Application of the Projects Approach to EFL" introduces a model which illustrates the process of project work in six steps:

Step 1: Preparation: in this period, the teacher introduces the topic to the students, and asks them to discuss 
and ask questions.

Step 2: Planning: in this period, the teacher and the students determine the mode for collecting and analyzing information, and different work are assigned.

Step 3: Research: in this part, the students work individually or in groups gather information from different sources.

Step 4: Conclusions: the students draw conclusions bases upon their analysis of the collected data.

Step 5: Presentation: the students are supposed to present their final product to the whole class.

Step 6: evaluation: in this part, the teacher makes comments on the students' endeavor and efforts.

In this model, Papandreou adds a new step into the whole process, namely evaluation, which is apparently a new initiative to the traditional model. And this model is similar to the six-step model undertaken by Kaptan.

Here are steps for implementing PBL, which are detailed below by (Korkmaz \& Kaptan, 2000):

Step 1: Stating the subject and sub-subjects, organizing the groups.

Students explore the resources and in order to create a frame for the project they state questions.

Step 2: Groups create projects.

Group members make a project plan. They ask questions as "Where are we going?”, "What will we learn?” vs. They choose their roles in the project.

Step 3: Application of the project.

Group members are organized and analyze the data and information.

Step 4: Planning of the presentation.

The members define the essential points in their presentation and then decide on how to present the project.

Step 5: Making the presentation.

Presentations can be made in any (in different schools, classes, vs.) places.

Step 6: Evaluation.

Students share the feedback of everyone on their project. Both the students and the teacher share the project(s) with everyone.

Based upon the above models, Stoller puts forward his initial eight steps framework, which is, to some extent, an improvement to the previous studies. In order to keep pace with time, this model is revised later. Stoller (2005) summarized the revised ten-step process in "maximizing the Benefits of Project Work in Foreign Language Classrooms”.

Step 1: Students and instructor agree on a theme for the project.

Step 2: Students and instructor determine the final outcome.

Step 3: Students and instructor structure the project.

Step 4: Instructor prepares students for the language demands of information gathering.

Step 5: Students gather information.

Step 6: Instructor prepares students for the language demands of compiling and analyzing data.

Step 7: Students compile and analyze information.

Step 8: Instructor prepares students for the language demands of the culminating activity.

Step 9: Students present final product.

Step 10: Students evaluate the project.

In this revised framework, steps 4, 6 and 8 are newly designed to differentiate it from the traditional one. The two models are different in that the language demands related to each step are taught in a different way.

The revised model is easier to handle and manage, which may help the teachers and students in the real application of the project. Thus the students' language skills, creative thinking and content learning can be facilitated. The final objective of the project work can be achieved.

\section{Other Relative Studies}

Apart from the theoretical studies on the definition and the process of Project-based learning, there are a large number of researches regarding the application of PBL in English language teaching, including academic papers, dissertations, textbooks and monographs.

The first paper on the application of PBL in English teaching probably is "A Project Course in Spoken English" by Roslyn Eslava and Peter Lawson. In this course a short episode of "silence movie" is adopted to engage the EFL students in the analysis of the film and the students are asked to produce a final dialogue based upon the 
situation. Although the research did not provide any empirical data, it is without any doubt that in this process, the students' motivation, autonomy, creativity and interest in English are increased.

Similarly, in Washington, D.C. research on the students from John Easton Elementary school found that nothing pulls the students' speaking and presentation skills together as effectively as Project-Based Learning. The study also demonstrated that PBL helps students in critical thinking, collaboration and communication.

Similar studies also proved the effectiveness of PBL in improving the critical thinking, problem-solving and overall skills. For instance, a study of PBL revealed "a positive effect on low-ability students, who increased their use of critical-thinking skills including synthesizing, evaluating, predicting, and reflecting by $446 \%$ while high-ability students improved by 76\%” (Horan et al., 1996).

Meanwhile, there are some articles in the literature in which the authors found that PBL is a challenge for language teachers, especially for those who have never used PBL before, which may result in the teachers' frustration, disappointment and other negative feelings. For instance, Ladewski, Krajcik and Harvey (1991) enlist the following challenges and conflicts encountered in the implementation of PBL: 1) Should time be most effectively used to allow students to pursue their own investigations or to cover the state-prescribed curriculum? 2) Should activities be designed to allow students to seek their own answers or be teacher-controlled so that (all) students obtain the same "correct" results? 3) Should students be given the responsibility for guiding their own learning or should the (more knowledgeable) teacher take responsibility for directing activities and disseminating information in the classroom?

In addition, Mar et al. (1997) demonstrated the teachers' problems and obstacles in implementing PBL as follows: 1) projects were time-consuming, 2) classrooms felt disorderly, 3) teachers could not control the flow of information, 4) it was difficult to balance giving students independence and providing them supports, 5) it was difficult to incorporate technology as a cognitive tool, and 6) authentic assessments were hard to design (Marx et al., 1997).

\section{Conclusion}

Based upon the review above, it is easy to draw the conclusion that PBL exerts great positive and beneficial effect on the students' academic achievements, namely the language skills, critical thinking and knowledge acquirement. Meanwhile, PBL is also a great challenge for the English teachers and students who are in need of help and support. Though there are many challenges and obstacles, the benefits without any doubts outweigh the disadvantages. The teacher should take all the possible factors related to the successful enactment into consideration, such as time, place, resources, students, technology and possible training.

\section{Acknowledgements}

This paper is under the project of Construction of Practical Teaching Base for English Majors (2014020207), The Nurturing of Cultural Awareness in Teaching English and American Literature (2014010214) and The Application of Project-Based Learning in Teaching Oral English. I am deeply indebted to all the team members, who have offered invaluable advice and comments.

\section{References}

Hedge, T. (1993). Key Concepts in ELT: Fluency and Project. ELT Journal, 3, 275-277. http://dx.doi.org/10.1093/elt/47.3.275

Horan, C., Lavaroni, C., \& Beldon, P. (1996). Observation of the Tinker Tech Program Students for Critical Thinking and Social Participation Behaviors. Novato, CA: Buck Institute for Education.

Katz, L. G., \& Chard, C. (2000). Engaging Children’s Minds: The Project Approach (2nd ed.). Connecticut: Ablex Publishing Corporation, Stamford.

Korkmaz, H., \& Kaptan, F. (2000). Fen Ogretiminde Proje Tabanli Ogrenme Yaklasimi. Hacettepe Universitesi Egitim Fakultesi Dergisi, 20, 193-200.

Marx, R. W., Blumenfeld, P. C., Krajcik, J. S., \& Soloway, E. (1997). Enacting Project-Based Science: Challenges for Practice and Policy. Elementary School Journal, 97, 341-358. http://dx.doi.org/10.1086/461870

Moss \& Van Duzer (1998). Project-Based Learning for Adult English Language Learners. Washington DC: National Center for ESL Literacy Education. 
Stoller, F. (2006). Establishing a Theoretical Foundation for Project-Based Learning in Second and Foreign Language Contexts. In G. H. Beckett, \& P. C. Miller, Eds., Project-Based Second and Foreign Language Education: Past, Present, and Future (pp. 19-40). Greenwich, CT: Information Age.

Thomas, J. W., \& Mergendoller, J. R. (2000). Managing Project-Based Learning: Principles from the Field. Paper Presented at the Annual Meeting of the American Educational Research Association, New Orleans. 